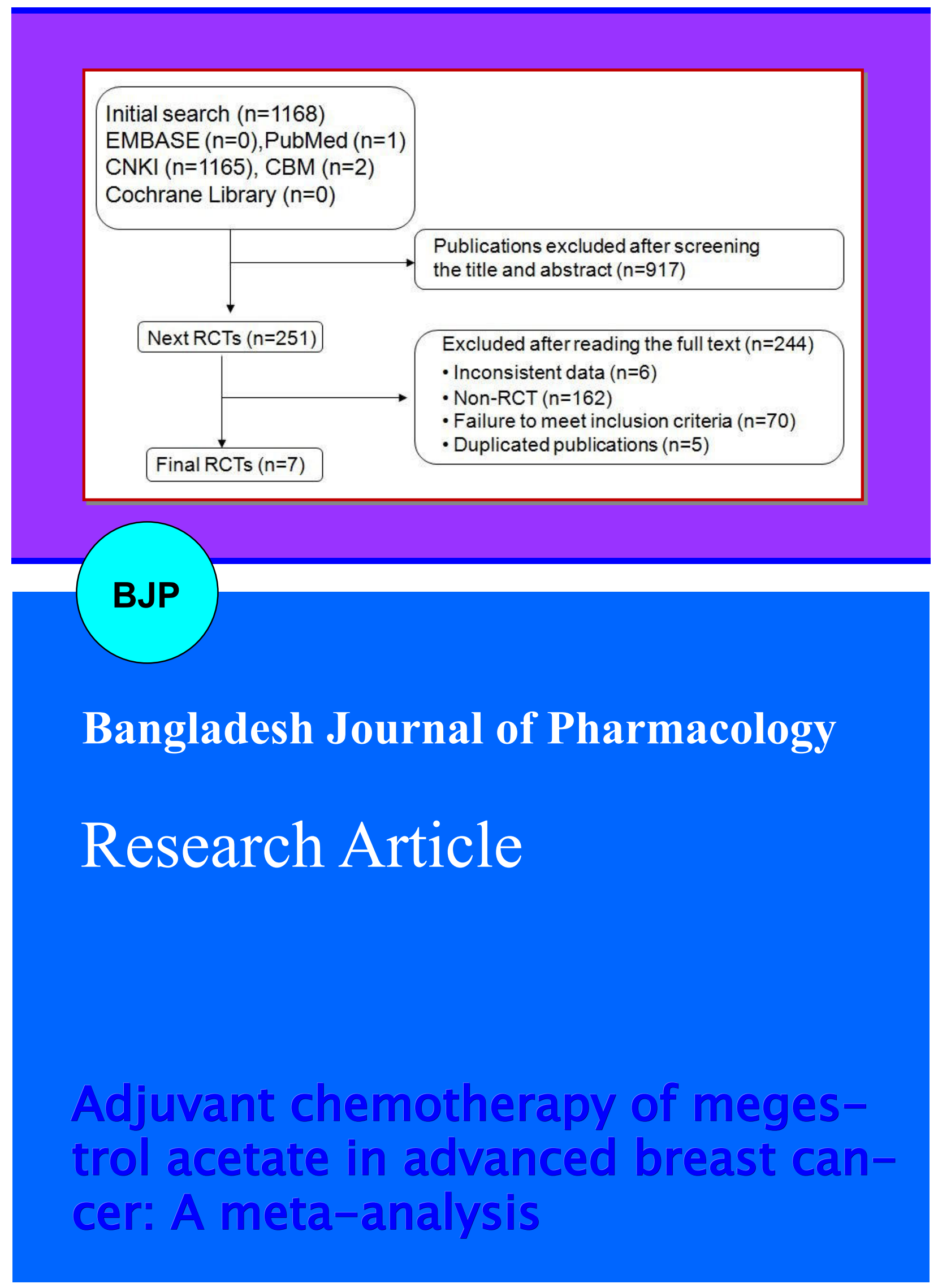




\title{
Adjuvant chemotherapy of megestrol acetate in advanced breast cancer: A meta-analysis
}

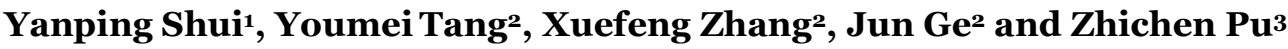 \\ ${ }^{1}$ Wannan Medical College, Wuhu, Anhui, 241001, China; ${ }^{2}$ Yantai Affiliated Hospital of Binzhou Medical \\ University, Yantai, Shandong 64 100, China; ${ }^{3}$ Institute of Drug Clinical Evaluation , Yijishan Hospital , Wannan \\ Medical College, Wuhu, Anhui, 241 001, China.
}

\begin{tabular}{|c|c|}
\hline \multicolumn{2}{|l|}{ Article Info } \\
\hline Received: & 17 February 2015 \\
\hline Accepted: & 24 March 2015 \\
\hline Available Online: & 24 April 2015 \\
\hline \multicolumn{2}{|c|}{ DOI: 10.3329/bjp.v10i2.22275 } \\
\hline \multicolumn{2}{|c|}{$\begin{array}{l}\text { Cite this article: } \\
\text { Shui Y, Tang Y, Zhang X, Jun Ge J, Pu } \\
\text { Z. Adjuvant chemotherapy of meges- } \\
\text { trol acetate in advanced breast cancer: } \\
\text { A meta-analysis. Bangladesh J Phar- } \\
\text { macol. 2015; 10: 383-92. }\end{array}$} \\
\hline
\end{tabular}

\section{Introduction}

Agency for research on cancer released data show that breast cancer has been the most frequently diagnosed cancer (Jemal et al., 2006). Human epidermal growth factor receptor 2 expression is referred to as triplenegative breast cancer (TNBC), representing about $15 \%$ of all breast cancers (Adamo et al., 2012). The leading cause of cancer death among females world wide, accounting for $23 \%$ of the total cancer cases and $14 \%$ of the cancer deaths in 2008, about 458,400 people, incidence increase rate by 0.2 to $8 \%$ annually. Currently, the incidence of breast cancer annual growth rate by 3 to $4 \%$, is higher than the global average growth rate in China (Pu et al., 2014; Zhai et al., 2015).

In recent years, megestrol acetate (MA) is one artificial semi-synthetic progesterone derivative, used to endocrine treatment on breast cancer and other hormone- dependent tumors (Fiorica et al., 2004). MA is applied to the non-hormone-dependent tumor treatment; has inhibitory effect of hormone dependence tumor line, especially breast cancer. At the same time, MA can improve patients' weight and appetite, alleviate gastrointestinal reaction and bone marrow suppression of adjuvant chemotherapy in advanced breast cancer (Demoor-Goldschmidt et al., 2009). MA has some roles of protein assimilation, can promote the patient's protein and fat synthesis; can increase or stabilize patient's weight, improve the quality of breast cancer patient's life in adjuvant chemotherapy period of advanced breast cancer (Partridge et al., 2001; Zhang et al., 2014). However, the results remain controversial. The purpose of our study is to meta-analyze data from randomized clinical trials (RCTs) for evidence on the adjuvant chemotherapy of MA treats patient with advanced breast cancer. 


\section{Materials and Methods}

\section{Literature search}

We searched CBM, CNKI, VIP, WangFang Data and PubMed, and RCT of adjuvant chemotherapy of MA in advanced breast cancer. The quality of included studies was assessed according to the criteria recommended by the Cochrane 4.2.6 Hand-book for systematic reviews of interventions, and meta-analyses were performed using the Cochrane Collabo-ration's RevMan 5.2 software (Fu et al., 2014). The reference lists of papers authenticated ware scanned for further trials. The under search labels were used con-junctively or individually: 'Breast Caner', 'Advanced Breast Caner', 'Megestrol Acetate', 'Randomized Con-trolled Trial', and 'Clinical Trial'.

\section{Inclusion and exclusion criteria}

\section{Inclusion criteria}

Type of research: RCT are updated to March 2013; object of observation: Selected patients (more than 18 years of age) is accord with national standard in the diagnosis of advanced breast cancer; intervening measure: MA vs placebo or margin or other therapy; curative effect decision criteria: Clear standard source of curative effect.

\section{Exclusion criteria}

Simple descriptive study has no control group or is not rigorous trial design; diagnosis and clinical criteria of RCT are not standardized; selected patient contains male patients; repeat reported; the sample data confessed unclear or incomplete etc.

\section{Quality assessment}

Three authors managed the literature searching, studied literature, and extracted data independently. Disagreement was resolved by discussion. The abstracted data included title and authors of study, study size, age, year of publication, details of methodological message, sex of the participants, name, specifics of the control interventions, treatment process, outcomes and adverse reaction for every research. At the same time, the 'risk of bias' assessment tool were used to assess all studies to address the following six criterion in accordance with the 'Cochrane 4.2.6 Hand-book of Systematic Reviews of Interventions': Randomization, allocation concealment, blinding, loss of imitation and exit cases, intention-to-treat (ITT) analysis, baseline, and Cochrane score. The quality of all the included studies was categorized to (C) low/ (B) unclear/ (A) high-risk of bias. These studies which met all criterions were categorized to (A) high-risk of bias, studies which met none of the criteria were categorized to (C) low-risk of bias, and other studies met some criterion were categorized to (B) unclear-risk of bias if insufficient information acquired to make judgment.

\section{Data extraction}

Read the title, summary and full text to extract data. Three researchers independently conducted quality assessment, and discussed the quality of each paper and decision.

\section{Data analysis}

We used RevMan 5.2 software to analysis data. Clinical heterogeneity and methodological hetero-geneity of the included studies were analyzed. $p$ values of $<0.05$ were considered significant.. Meta-analysis was utilized if the studies had receivable homogeneity of study design, controls, interventions, participants, and outcome measures. The statistical heterogeneity was tested by examining $\mathrm{I}^{2}$ square 15 or $\mathrm{p}$ value; an $\mathrm{I}^{2}>50 \%$ or a $\mathrm{p}$ value $<0.1$ indicates the possibility of statistical heterogeneity (Zhang et al., 2013). $\mathrm{I} 2<25 \%$ is low heterogeneity, $25 \% \leq \mathrm{I}^{2} \leq 50 \%$ is moderate heterogeneity and $\mathrm{I}^{2}>50 \%$ is highly heterogeneous. Data was summarized using risk ratio (RR) with 95\% confidence intervals (CI) for binary outcomes or mean difference (MD) with a 95\% CI for continuous outcomes. Publication bias was explored by way of a funnel-plot analysis (Ciliberto et al., 2012). Missing or lost to cases count data should be counted as treatment failure cases. So we have demonstrated sensitivity analysis.

\section{Results}

\section{Description of studies}

We searched primarily from the five databases, 2240 documents were screened. We eliminated duplicate 1259 documents by electronic and hand searches. We eliminated 368 documents with review of literature/ time too long literature/the no-research object. We eliminated 591 documents with non-randomized controlled trial/interventions and the results have not met the inclusion criteria by reading abstract. We eliminated 14 documents with data in question/ random method is not correct by reading full text. Finally full-text papers of 8 studies (Cao et al., 2012; Feng, 2012; Gong et al., 2012; Goodwin et al., 2008; Lu et al., 2012; Tang et al., 2012; Tang et al., 2012; Zhou et al., 2012) were searched from all the citations. A flowchart described the search method and study chose (Figure $1)$.

\section{General characteristics of included reviews}

These 8 trials literature included the 610 cases including 307 cases of MA group and 303 cases of the control group. These studies were the largest number of 194 cases, at least 28 cases. In the 8 included trials, the treatment efficiency was reported by 4 trials, the gain weight was reported by 3 trials, the increased appetite was reported by 4 trials, the improve KPS was reported 


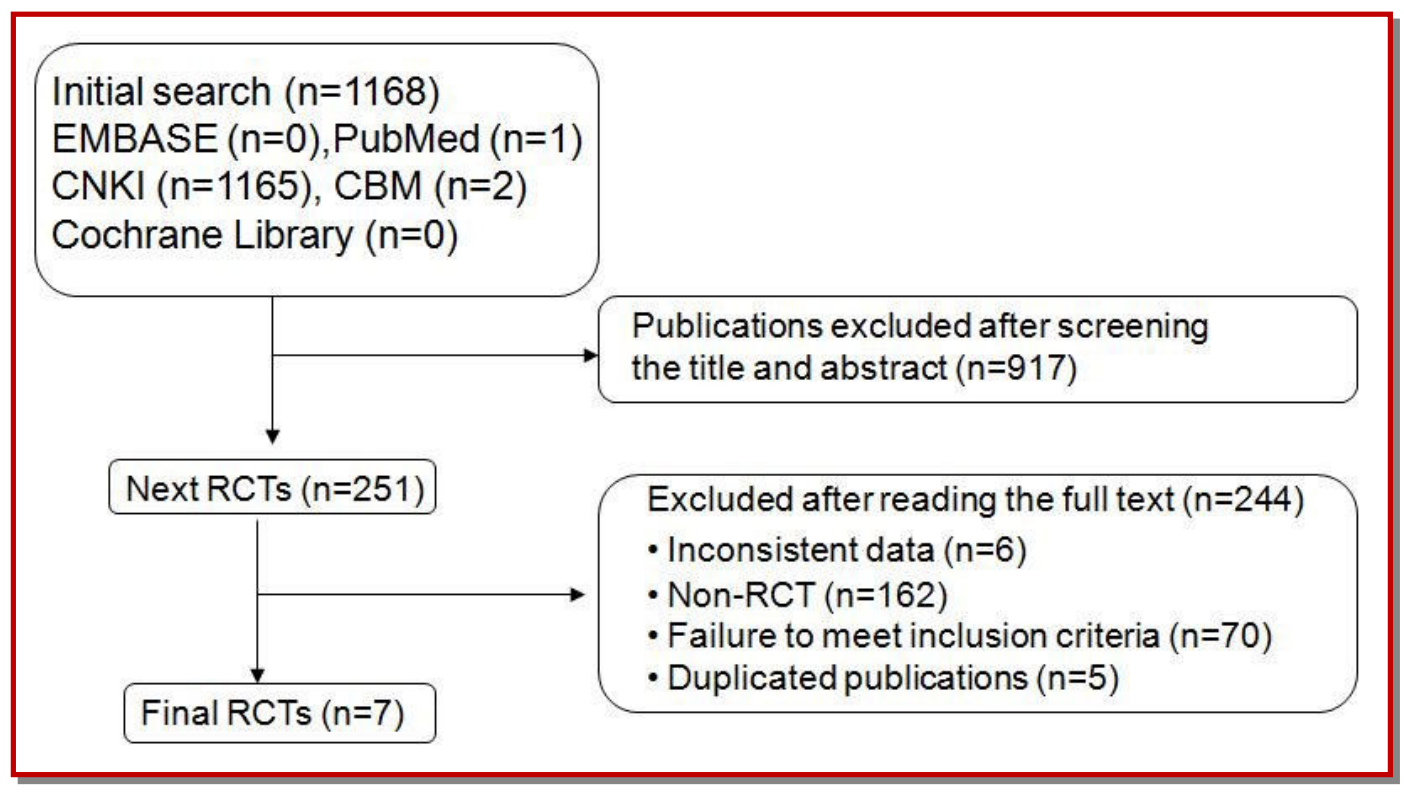

Figure 1: Flowchart of identification of studies included in the review

by 3 trials, the leukopenia was reported by 3 trials, the thrombocytopenia was reported by 3 trials, the hemoglobin was reported by 3 trials and the gastrointestinal tract bad effect was reported by 3 trials of adjuvant chemotherapy of advanced breast cancer patients. The features of included studies were cataloged in Table I.

\section{Methodological quality of included reviews}

Eight studies were assessed in accordance with the 'Cochrane 4.2.2 Handbook of Systematic Reviews', including 1 study was categorized to (B) unclear-risk of bias, 7 studies were categorized to (C) low-risk of bias. All studies had no sample estimate and belonged to low quality of research. The basic situation of these studies was shown in Table II.

\section{Effect estimates}

All studies alleged active effects useful though many of the studies turned out to be effective, when analyzed by standard statistical skills using mean differences or odds ratios.

\section{Treatment efficiency}

The 4 included trials with treatment efficiency of adjuvant chemotherapy of MA in advanced breast cancer were reported, which included 280 patients. Meta-analysis showed, MA group and the control group were $101 / 135,60 / 145$. The heterogeneity test results $\mathrm{p}=0.005, \mathrm{I}^{2}=77 \%$. We had chosen random effects model (REM). $Z=2.58, \mathrm{RR}=1.75,95 \% \mathrm{CI}$ [1.14 2.67], $\mathrm{p}<0.0010$. The results show the treatment efficiency of adjuvant chemotherapy of advanced breast cancer in MA group was significantly higher than the control group (Figure 2).
The nutritional situation of the advanced breast cancer patient

The 4 included trials reported patient's nutritional situation of adjuvant chemotherapy of MA in advanced breast cancer was reported. Meta-analysis showed, $\mathrm{p}=$ $0.004, \mathrm{I}^{2}=63 \%$. We had chosen REM. $\mathrm{Z}=4.22, \mathrm{RR}=$ 2.10, 95\% CI [1.49 2.97], p<0.0001. The results showed, MA can markedly improve the patient's nutritive condition in adjuvant chemotherapy of advanced breast cancer (Figure 3, Table III).

\section{The bone marrow suppression situation of the patient}

The 3 included trials with the bone marrow suppression situation of adjuvant chemotherapy of MA in advanced breast cancer were reported. Meta-analysis showed, $\mathrm{p}=$ $0.62, \mathrm{I}^{2}=0 \%$. We had chosen FEM. $\mathrm{Z}=3.99, \mathrm{RR}=0.45$, $95 \%$ CI [0.31 0.67], $\mathrm{p}<0.0001$. The results showed, Summary, MA can markedly reduce the adverse reaction of the patient's bone marrow in adjuvant chemotherapy of advanced breast cancer (Figure 4, Table III).

\section{The gastrointestinal reaction of the patient}

The 3 included trials with patient's gastro-intestinal reaction of adjuvant chemotherapy of MA in advanced breast cancer were reported, which included 338 patients. Meta-analysis showed, MA group and the control group were 39/172,68/166. The heterogeneity test results $\mathrm{p}=0.60, \mathrm{I}^{2}=0 \%$. We had chosen FEM. $\mathrm{Z}=$ $3.44, \mathrm{RR}=0.57,95 \% \mathrm{CI}[0.41 \sim 0.79], \mathrm{p}=0.0006$. The results show that MA can markedly reduce gastrointestinal tract bad effect in adjuvant chemotherapy of advanced breast cancer (Figure 5).

Heterogeneity analysis 


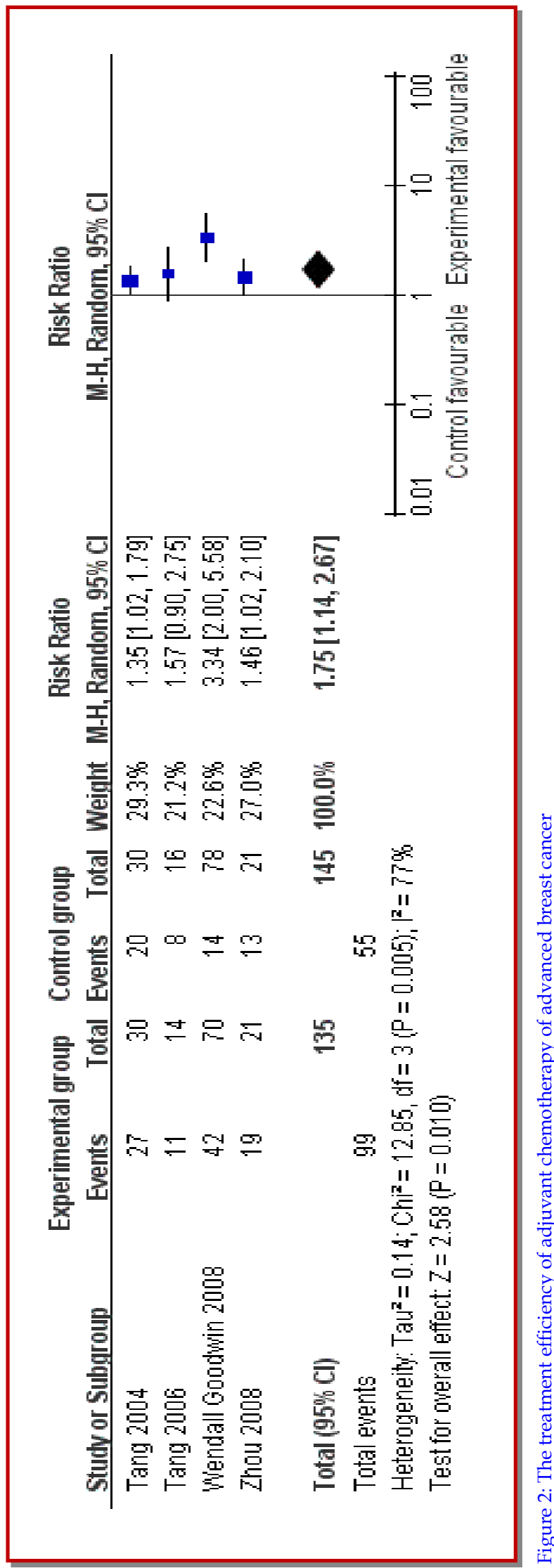

There were 8 indexes in this study. The homogeneity of 5 indexes $\left(\mathrm{I}^{2}=0 \%\right)$ was satisfactory, which develop heterogeneity analysis. The homogeneity of 1 index was moderate $\left(25 \%<\mathrm{I}^{2}<50 \%\right)$, which was selected FEM. The homogeneity of 1 index was high ( $\left.\mathrm{I}^{2}>50 \%\right)$, which was selected REM. The homogeneity of 1 index was too high $\left(\mathrm{I}^{2}>75 \%\right)$, which was descriptive analysis. We have analyzed the reason for the formation of heterogeneity, for example, KPS and gastrointestinal reaction. The measuring methods and technical means were very variable in the different years and different areas. In the meantime, the measuring time of many researches was big variable too. Homogeneity of study results was preferably, because the evaluation criterion of better homogeneity indexes was more objective.

\section{The result of sensitivity analysis}

In the 8 included trials, 2 pieces reported 7 loss of patients. The sensitivity analysis showed that with low quality trials precluded, the summary RR and 95\% CIs for above effects were still similar to the results before they were eliminating (Table IV), which indicates that the results of our studies were believable and responsible.

\section{Discussion}

Comprehensive literature evaluation, clinical effects of adjuvant chemotherapy of MA in breast cancer, including: 1) treatment efficiency, $\mathrm{p}=0.0010$; 2) gain body weight, $\mathrm{p}<0.0001 ; 3)$ increased appetite, $\mathrm{p}=0.001$; 4) improve KPS, $p=0.06$; 5) leucopenia, $p=0.02 ; 6$ ) thrombocytopenia, $\mathrm{p}=0.02 ; 7$ ) hemoglobin, $\mathrm{p}=0.01$; and 8) gastrointestinal reaction of the patient, $\mathrm{p}=$ 0.0006. MA significantly increased treatment efficiency, markedly improve the patient's nutritional situation, reduce the adverse reaction of the patient's bone marrow and gastrointestinal tract in adjuvant chemotherapy of advanced breast cancer, $\mathrm{p}<0.001$.

TNBC has an aggressive clinical phenotype with early brain and other distant metastases and a poor prognosis (Lin et al., 2012). MA, a semisynthetic progestin, is among the most commonly used, especially in the United States, while in European countries the drug has not yet gained widespread acceptance. Its efficacy has been documented in several studies which suggested that postmenopausal patients, treatment with this agent can expected to yield about $20-30 \%$ objective responses. Clinical studies found that MA can improve appetite, increase food intake, promoted protein and fat synthesis of adjuvant chemotherapy in advanced breast cancer patients (Jang et al., 2011; Lara-Medina et al., 2011). MA has a certain degree of protection function of bone marrow and direct treatment of cancer role. In vitro experiments showed that MA can inhibit mitosis and activation of stem cell, these cells hold in the G0 


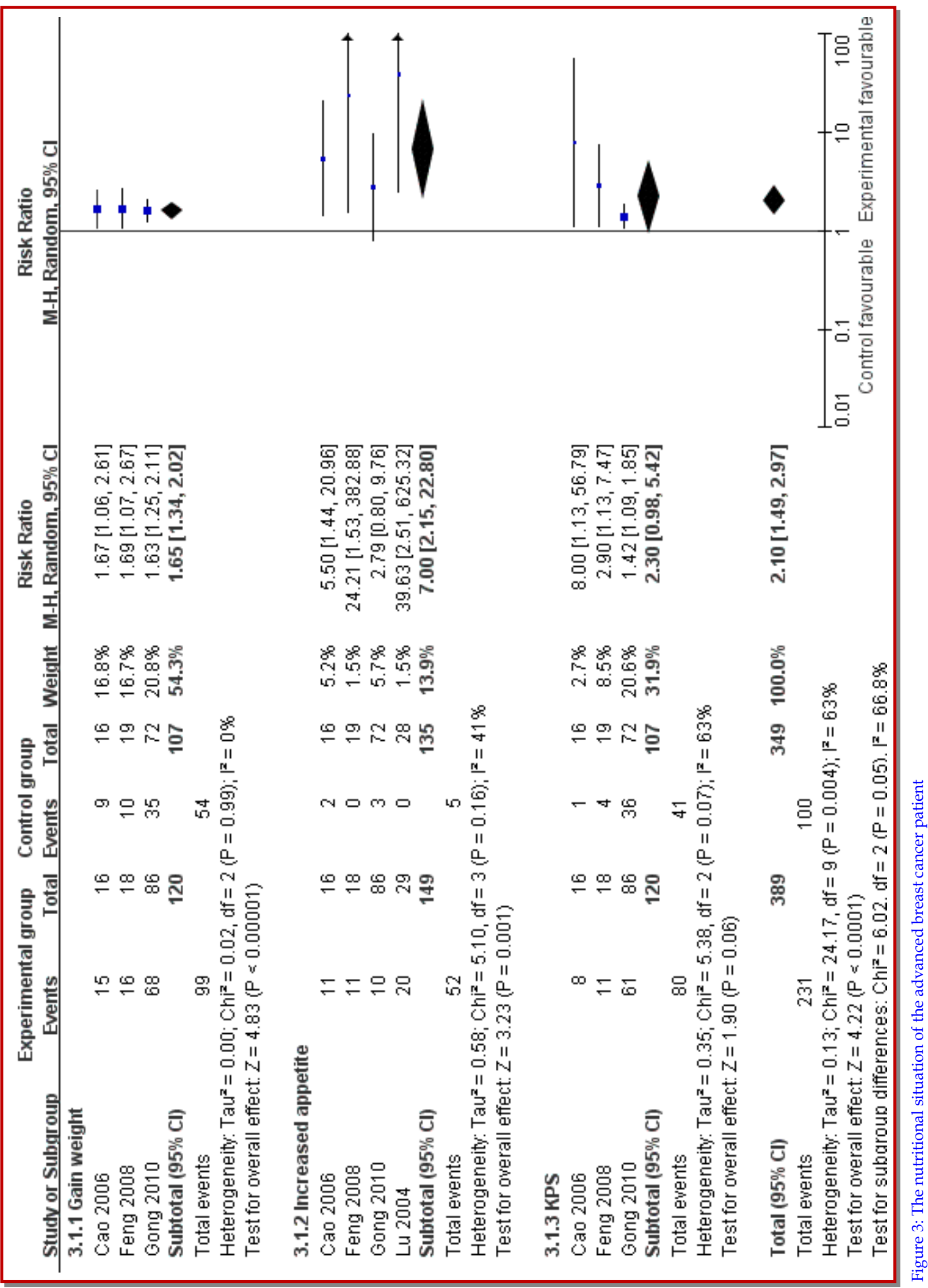




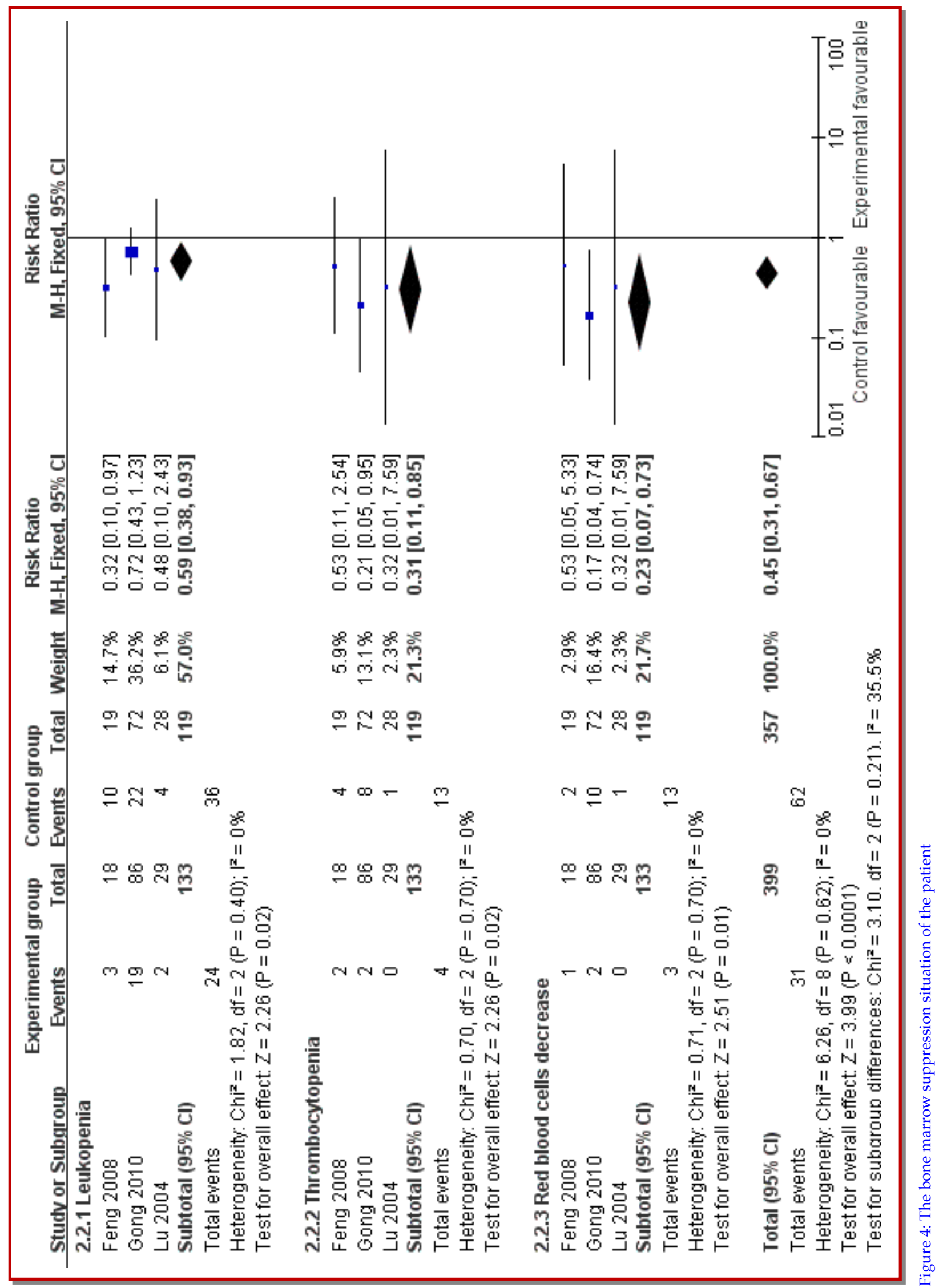




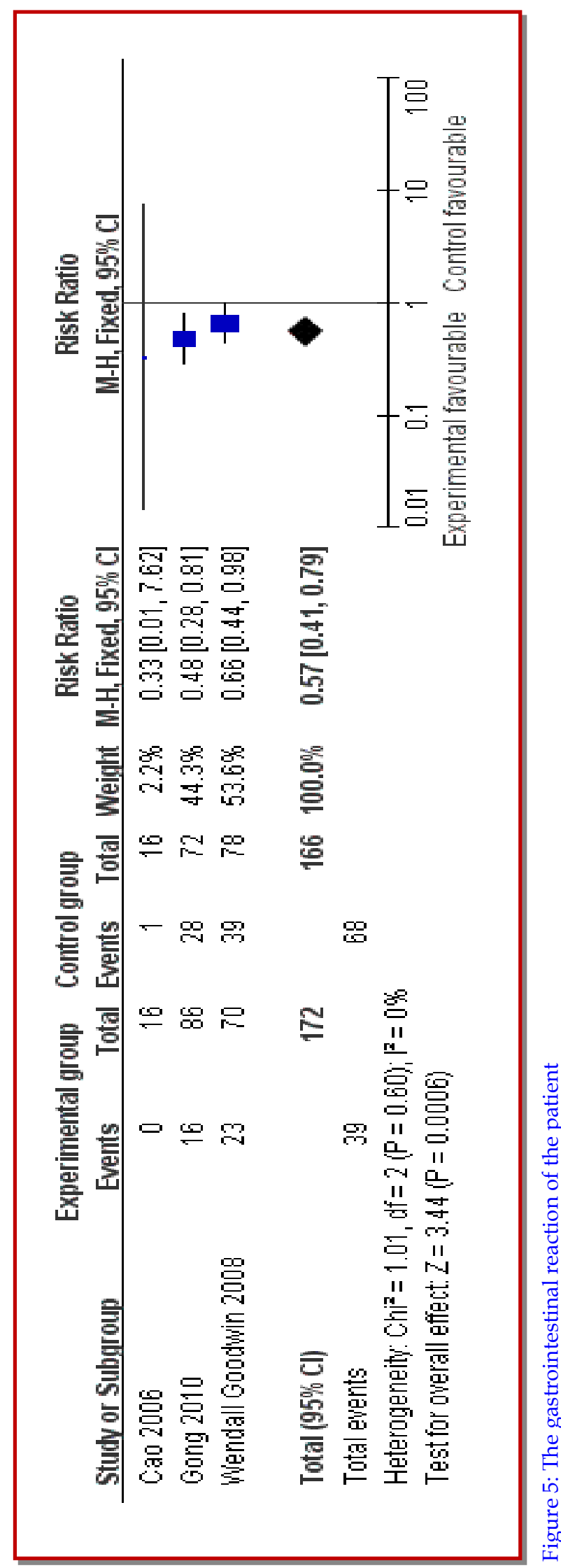

phase. Thus, MA can maintain a normal number of neutrophile granulocyte in peripheral blood, ensure the normal conduct of chemotherapy, help to maintain the continuity of chemotherapy and improve tolerance to chemotherapy of patients (Licchetta et al., 2010). In summary, MA is a chemotherapy adjuvant drugs, can improve the nutritional status of patients, reduce the complications of chemotherapy and improve chemotherapy in advanced breast cancer. As a result, MA has great clinical application value.

In summary, 2 studies (25\%) described the random method and process in $8 \mathrm{RCT}$, the other experiments mention "Random". None reported distribution, hiding scheme and double-blind method. 2 studies (25\%) reported loss of cases and confessed exit reason, the dropout rate from 8.1 to $23.7 \%$. Randomized reported rate of RCT was $48.9 \%$ in domestic core journals (Mills et al., 2005) and $48 \%$ abroad (Moher et al., 2012). The improper use of random method/pseudo-random caused selective bias and great impact of the test results. This is the inadequacies of the study. At the same time, all literature reported pathological grading and staging of patients, treatment programs etc. The results showed that baseline characteristics between experimental and control groups was basically consistent, $\mathrm{p}>0.05$.

These 8 trials literature were included 610 cases including 307 cases of MA group and 303 cases of the control group. These studies were the largest number of 194 cases, at least 28 cases. The average number of 38.4 cases of MA group and the average number of 37.9 cases of the control group. 2 studies (25\%) were study population $\geq 100$ cases. Sample size is too small in all trials, which reduced the accuracy of the test results and increased incidence of type II error. This is the inadequacies of the study. At same time, an important factor was the low-quality randomized controlled trials.

The next trials will furnish message about standardization including specific regimen, duration and quality control of treatment. Our study suggested that the future studies will avoid low-level redundant and design experiment of multicenter, large sample randomized controlled double-blind trial. Experimental methodology will use CONSORT 2010 standards to report experiment of fully random, fully implement allocation concealment and loss and exit of patients (Ciliberto et al., 2012). We wished that the more negative results of clinical trials will be report. We hoped that these advancing studies will be report in the future. High-qualified proof will come out afford clinical evidence for adjuvant chemotherapy of MA on advanced breast cancer.

\section{References}

Adamo V, Ricciardi GR, De Placido S, Colucci G, Conte P, 
Table I

Baseline characteristics of the eligible trials

\begin{tabular}{|c|c|c|c|c|c|c|c|}
\hline References & Randomization & $\begin{array}{c}\text { Allocation } \\
\text { concealment }\end{array}$ & $\begin{array}{l}\text { The form of } \\
\text { double-blind }\end{array}$ & $\begin{array}{l}\text { Loss of imitation } \\
\text { and exit cases }\end{array}$ & $\begin{array}{c}\text { ITT } \\
\text { analysis }\end{array}$ & $\begin{array}{l}\text { Base- } \\
\text { line }\end{array}$ & $\begin{array}{l}\text { Cochrane } \\
\text { Score }\end{array}$ \\
\hline $\begin{array}{l}\text { Lu and Ding, } \\
2004\end{array}$ & Unclear & Unclear & Unclear & Clear & Unclear & Yes & $\mathrm{C}$ \\
\hline Feng, 2008 & Unclear & Unclear & Unclear & Unclear & Unclear & Yes & C \\
\hline Gong et al., 2010 & Unclear & Unclear & Unclear & Unclear & Unclear & Yes & $\mathrm{C}$ \\
\hline $\begin{array}{l}\text { Tang and Luo, } \\
2004\end{array}$ & Unclear & Unclear & Unclear & Unclear & Unclear & Yes & C \\
\hline $\begin{array}{l}\text { Cao and Jiao, } \\
2006\end{array}$ & Unclear & Unclear & Unclear & Unclear & Unclear & Yes & $\mathrm{C}$ \\
\hline $\begin{array}{l}\text { Tang and Duan, } \\
2006\end{array}$ & Unclear & Unclear & Unclear & Unclear & Unclear & Yes & C \\
\hline Zhou et al., 2008 & Unclear & Unclear & Unclear & Unclear & Unclear & Yes & $\mathrm{C}$ \\
\hline $\begin{array}{l}\text { Goodwin et al., } \\
2008\end{array}$ & Registered & Unclear & Unclear & Clear & Unclear & Yes & B \\
\hline
\end{tabular}

Table II

Methodological quality scores

\begin{tabular}{|c|c|c|c|c|c|}
\hline References & $\begin{array}{l}\text { Sample size } \\
(\mathrm{Rx}=\mathrm{C})\end{array}$ & $\begin{array}{l}\text { Age (yr, } \\
\text { Rx=C) }\end{array}$ & Experimental intervention & $\begin{array}{l}\text { Control inter- } \\
\text { vention }\end{array}$ & $\begin{array}{l}\text { Duration of } \\
\text { treatments }\end{array}$ \\
\hline $\begin{array}{l}\text { Lu and Ding, } \\
2004\end{array}$ & $29 / 28$ & 47.6 & Megestrol acetate $(80 \mathrm{mg} / \mathrm{d})$ & Placebo & $6-13 W$ \\
\hline Feng, 2008 & $18 / 19$ & $48 / 46$ & $\begin{array}{l}\text { Megestrol acetate }(160 \mathrm{mg} / \mathrm{d}) \\
\text { plus conventional chemotherapy }\end{array}$ & $\begin{array}{l}\text { Conventional } \\
\text { chemotherapy }\end{array}$ & $1 \mathrm{~W}$ \\
\hline $\begin{array}{l}\text { Gong et al., } \\
2010\end{array}$ & $86 / 72$ & - & $\begin{array}{l}\text { Megestrol acetate }(160 \mathrm{mg} / \mathrm{d}) \\
\text { plus CEF }\end{array}$ & CEF & $21 \mathrm{D}$ \\
\hline $\begin{array}{l}\text { Tang and Luo, } \\
2004\end{array}$ & $30 / 30$ & $52-62$ & $\begin{array}{l}\text { Megestrol acetate }(160 \mathrm{mg} / \mathrm{d}) \\
\text { plus CEF plus ondansetron }(8 \\
\mathrm{mg})\end{array}$ & $\begin{array}{c}\text { CEF plus on- } \\
\text { dansetron }(8 \mathrm{mg})\end{array}$ & $6 \times 21 \mathrm{D}$ \\
\hline $\begin{array}{l}\text { Cao and Jiao, } \\
2006\end{array}$ & $16 / 16$ & $38-67$ & $\begin{array}{l}\text { Megestrol acetate }(2 \times 160 \mathrm{mg} / \mathrm{d}) \\
\text { plus Aspirin }(50 \mathrm{mg})\end{array}$ & Aspirin (50 mg) & $2 \mathrm{~W}$ \\
\hline $\begin{array}{l}\text { Tang and } \\
\text { Duan, } 2006\end{array}$ & $16 / 14$ & $35-62$ & $\begin{array}{l}\text { Megestrol acetate }(160 \mathrm{mg} / \mathrm{d}) \\
\text { plus pamidronate }(60 \mathrm{mg} / 21 \mathrm{~d} \\
\text { plus MS Contin tablet }(2 \times 30 \mathrm{mg})\end{array}$ & $\begin{array}{l}\text { MS Contin tablet } \\
\quad(2 \times 30 \mathrm{mg})\end{array}$ & $>8 \mathrm{~W}$ \\
\hline $\begin{array}{l}\text { Zhou et al., } \\
2008\end{array}$ & $21 / 21$ & 50.2 & $\begin{array}{l}\text { Megestrol acetate }(250 \mathrm{mg}) \text { plus } \\
\text { Zoledronic acid }(4 \mathrm{mg} / \mathrm{M})\end{array}$ & $\begin{array}{l}\text { Zoledronic acid } \\
\qquad(4 \mathrm{mg} / \mathrm{M})\end{array}$ & $\begin{array}{l}>6 \mathrm{~W} \text { Megestrol plus } \\
\text { 3-4M Zoledronic } \\
\text { acid }\end{array}$ \\
\hline $\begin{array}{l}\text { Goodwin et } \\
\text { al., } 2008\end{array}$ & $93 / 101$ & $38-78 / 35-82$ & Megestrol acetate (160 mg) & Placebo & $3 \mathrm{M}$ \\
\hline
\end{tabular}

Giuffrida D, Gebbia N, Masci G, Cognetti F, Dondi D, Venturini M. Management and treatment of triple-negative breast cancer patients from the NEMESI study: An Italian experience. Eur J Cancer. 2012; 48: 642-47.

Cao XL, Jiao JP. In chemotherapy period clinical observation: Megestrol improve the life quality of patients with advanced breast cancer. Mod Med Tumor. 2006; 14: 48-49.

Ciliberto D, Prati U, Roveda L, Barbieri V, Staropoli N, Abbru- zzese A, Caraglia M, Di Maio M, Flotta D, Tassone P, Tagliaferri P. Role of systemic chemotherapy in the management of resected or resectable colorectal liver metastases: A systematic review and meta-analysis of randomized controlled trials. Oncol Rep. 2012; 27: 1849-56.

Demoor-Goldschmidt C, Raynard B. How can we integrate nutritional support in medical oncology? Bull Cancer. 2009; 96: 665-75. 
Table III

The nutritional situation and bone marrow suppression situation of the patient

\begin{tabular}{|lcccc|}
\hline Adverse reactions & MA group & Control group & RR [95\% CI] & $\mathrm{p}$ value \\
\hline Weight gain & $99 / 120$ & $54 / 107$ & $1.65[1.34,2.02]$ & $\mathrm{p}<0.00001$ \\
Increased appetite & $52 / 149$ & $5 / 135$ & $7.00[2.15,22.08]$ & $\mathrm{p}=0.001$ \\
KPS & $80 / 120$ & $41 / 107$ & $2.30[0.98,5.42]$ & $\mathrm{p}=0.06$ \\
Leucopenia & $24 / 133$ & $36 / 119$ & $0.59[0.38,0.93]$ & $\mathrm{p}=0.02$ \\
Thrombocytopenia & $4 / 133$ & $13 / 119$. & $0.31[0.11,0.85]$ & $\mathrm{p}=0.02$ \\
Hemoglobin & $3 / 133$ & $13 / 119$ & $0.23[0.07,0.73]$ & $\mathrm{p}=0.01$ \\
\hline
\end{tabular}

Table IV

\begin{tabular}{|llcclc|}
\hline & \multicolumn{5}{c}{ Sensitivity analysis } \\
\hline References & Item & $\begin{array}{c}\text { Excluding ago } \\
\text { RR }[95 \% \text { CI }]\end{array}$ & $\begin{array}{c}\text { After Excluding } \\
\text { RR [95\% CI] }\end{array}$ & $p$ value & $\begin{array}{c}\text { Statistical } \\
\text { significance }\end{array}$ \\
\hline Lu and Ding, 2004 & Increased appetite & $7.00[2.15,22.08]$ & $7.02[2.14,23.31]$ & $p=0.001$ & No difference \\
Lu and Ding, 2004 & Leucopenia & $0.59[0.38,0.93]$ & $0.59[0.38,0.94]$ & $p=0.02$ & No difference \\
Lu and Ding, 2004 & Thrombocytopenia & $0.31[0.11,0.85]$ & $0.31[0.11,0.86]$ & $\mathrm{p}=0.02$ & No difference \\
Lu and Ding, 2004 & Hemoglobin & $0.23[0.07,0.73]$ & $0.23[0.07,0.72]$ & $\mathrm{p}=0.01$ & No difference \\
Goodwin et al., 2008 & Treatment efficiency & $1.75[1.14,2.67]$ & $1.75[1.14,2.67]$ & $\mathrm{p}=0.010$ & No difference \\
Goodwin et al., 2008 & Gastrointestinal reactions & $0.57[0.41,0.79]$ & $0.57[0.41,0.79]$ & $\mathrm{p}=0.0006$ & No difference \\
\hline
\end{tabular}

Feng GF. Chemotherapy of megestrol acetate auxiliary on breast Jemal A, Siegel R, Ward E, Murray T, Xu J, Smigal C, Thun MJ. cancer: A clinical research. China's Health Care Nutr J Clin Cancer statistics, 2006. CA Cancer J Clin. 2006; 56: 106-30. Med. 2008; 27: 19-20.

Fiorica JV, Brunetto VL, Hanjani P, Lentz SS, Mannel R, Andersen W. Phase II trial of alternating courses of megestrol acetate and tamoxifen in advanced endometrial carcinoma: A Gynecologic Oncology Group study. Gynecol Oncol. 2004; 92: $10-14$.

Fu Y, Zhuang Z. Long-term effects of levonorgestrel-releasing intrauterine system on tamoxifen-treated breast cancer patients: A meta-analysis. Int J Clin Exp Pathol. 2014; 7: 641929.

Gong Y, Li ZH, Chen G, Cao YL. Neo-adjuvant chemotherapy of megestrol acetate in bereast cancer: Short-term clinical study. Int J Surg. 2010; 37: 17-20.

Goodwin JW, Green SJ, Moinpour CM, Bearden JD, 3rd, Giguere JK, Jiang CS, Lippman SM, Martino S, Albain KS. Phase III randomized placebo-controlled trial of two doses of megestrol acetate as treatment for menopausal symptoms in women with breast cancer: Southwest Oncology Group Study 9626. J Clin Oncol. 2008; 26: 1650-56.

Jang G, Lee SS, Ahn JH, Jung KH, Lee H, Gong G, Kim HH, Ahn $\mathrm{SD}$, Son $\mathrm{BH}, \mathrm{Ahn} \mathrm{SH}$, Kim SB. Clinical features and course of brain metastases in triple-negative breast cancer: Comparison with human epidermal growth factor receptor 2-positive and other type at single institution in Korea. Breast Cancer Res Treat. 2011; 128: 171-77.
Lara-Medina F, Perez-Sanchez V, Saavedra-Perez D, BlakeCerda M, Arce C, Motola-Kuba D, Villarreal-Garza C, Gonzalez-Angulo AM, Bargallo E, Aguilar JL, Mohar A, Arrieta O. Triple-negative breast cancer in hispanic patients: High prevalence, poor prognosis, and association with menopausal status, body mass index, and parity. Cancer. 2011; 117: 3658-69.

Licchetta A, Correale P, Migali C, Remondo C, Francini E, Pascucci A, Magliocca A, Guarnieri A, Savelli V, Piccolomini A, Carli AF, Francini G. Oral metronomic chemo-hormonaltherapy of metastatic breast cancer with cyclophosphamide and megestrol acetate. J Chemother. 2010; 22: 201-04.

Lin C, Chien SY, Kuo SJ, Chen LS, Chen ST, Lai HW, Chang TW, Chen DR. A 10-year follow-up of triple-negative breast cancer patients in Taiwan. Jpn J Clin Oncol. 2012; 42: 161-67.

Lu WB, Ding H. Adjuvant treatment of megestrol acetate (MPA) on breast cancer chemotherapy patients: A clinical observation. China New Med. 2004; 27: 101-02.

Mills EJ, Wu P, Gagnier J, Devereaux PJ. The quality of randomized trial reporting in leading medical journals since the revised CONSORT statement. Contemp Clin Trials. 2005; 26: 480-87.

Moher D, Hopewell S, Schulz KF, Montori V, Gotzsche PC, Devereaux PJ, Elbourne D, Egger M, Altman DG. CONSORT 2010 explanation and elaboration: Updated guidelines for 
reporting parallel group randomised trials. Int J Surg. 2012; 10: 28-55.

Partridge AH, Burstein HJ, Winer EP. Side effects of chemotherapy and combined chemohormonal therapy in women with early-stage breast cancer. J Natl Cancer Inst Monogr. 2001; 2001: 135-42.

Pu Z, Yuan X, Zhang X, Chen Q, Xie H. Meta-analysis on the association between CYP2D6*10 gene polymorphism and disease free survival of breast cancer patients receiving tamoxifen treatment in Asia. Bangladesh J Pharmacol. 2014; 9: 652-62.

Tang LX, Luo FM. Treatment of postmenopausal breast cancer with chemotherapy and megestrol tablet: Clinical observation. Chinese J Gerontol. 2004; 8: 762.

Tang Z, Duan XQ. Para meters disodium phosphate joint point a progestin improve quality of life in patients with advanced breast cancer bone metastasis. Mod Med Tumor. 2006; 14: 163-64.
Zhai Z, Qu X, Li H, Ouyang Z, Yan W, Liu G, Liu X, Fan Q, Tang T, Dai K, Qin A. Inhibition of MDA-MB-231 breast cancer cell migration and invasion activity by andrographolide via suppression of nuclear factor-kappaB-dependent matrix metalloproteinase-9 expression. Mol Med Rep. 2015; 11: $1139-45$.

Zhang F, Kang H, Xu Q. Estrogen increases secretion of stromal cell derived factor-1 in human breast cancer cells. Int J Clin Exp Med. 2014; 7: 5529-34.

Zhang Y, Li S, Xiao HQ, Hu ZX, Xu YC, Huang Q. Vascular endothelial growth factor gene polymorphisms and renal cell carcinoma: A systematic review and meta-analysis. Oncol Lett. 2013; 6: 1068-78.

Zhou ZB, Liu YC, Gao F, Yan HX, Zhao Y, Yin XX. Combined curative effect observation of point a progestin treatment with azole to phosphonic acid and megestrol on breast cancer bone metastasis. Basic and clinical tumor. J Basic Clin Oncol. 2008; 21: 80. 